\title{
The Influence of Bank Ownership on Bank Performance and Risks (The Case of Sharia Commercial Banks in Indonesia)
}

\section{Sellen Ravindy ${ }^{1}$, Nisful Laila ${ }^{2}$, Lina Nugraha Rani ${ }^{2}$, and Puji Sucia Sukmaningrum²}

${ }^{1}$ Student of Islamic Economics Undergraduate Program, Faculty of Economics and Business Airlangga University

${ }^{2}$ Department of Islamic Economics, Faculty of Economics and Business -Airlangga University

\section{Abstract}

This research aims to find out the influence of bank ownership (domestic, foreign, state-owned, or private) on bank performance and risks in Sharia Commercial Banks in Indonesia. This research uses quantitative approach with multiple linear regression analysis technique. The results of the research show that variable of Domestic-Foreign

Corresponding Author:

Sellen Ravindy

sellen.ravindy-

2014@feb.unair.ac.id

Received: 10 February 2019

Accepted: 14 March 2019

Published: 28 March 2019

Publishing services provided by Knowledge E

(c) Sellen Ravindy et al. This article is distributed under the terms of the Creative Commons Attribution License, which permits unrestricted use and redistribution provided that the original author and source are credited.

Selection and Peer-review under the responsibility of the ICIEBP Conference Committee. Bank has positive significant effects, variable of State Owned-Private Bank has negative not significant effects on the Return on Assets, and variable of Domestic-Foreign Bank has positive significant effects, variable of State Owned-Private Bank has negative significant effects to the Non-Performing Financing on Sharia Commercial Banks in Indonesia.

Keywords: Ownership of Domestic-Foreign Bank, Ownership of State Owned-Private Bank, Return on Assets, Non-Performing Financing.

\section{Introduction}

Banking industry is one of Indonesia's economic pillars and it plays a strategic role especially in collecting fund from the public and distributing it to finance economic activities (Siregar, 1990). The establishment of sharia banks aims to form a financial institution with Islamic principles as its foundation to do banking activities. In doing their activities, sharia banks do not only focus on making maximum profit, but also take public welfare into consideration.

Company management is separated between the manager as an agent and the owner as a principal in modern economy. This conforms to the agency theory where stakeholders trust a manager or professionals to do fund arrangement and the manager takes responsibility for that. Problems often arise from the separation if both parties have

\section{S OPEN ACCESS}


There are many ways for assessing company performance, one of them is profitability. Profitability ratio assesses a company's ability to make profit using resources it owns, such as assets, capital, or company sales (Sudana, 2009: 22). The indicator of profitability ratio used in this research is Return on Assets (ROA).

In assessing the level of banking risks, the number of non-performing financing is the defining factor. Non-Performing Financing (NPF) is an indicator to assess the level of financing risks. The higher the NPF ratio, the more non-performing financing a bank has to handle. This situation indicates problems of liquidity (third party's inability to pay), solvability (decreasing capital), and rentability (bank's inability to make profit). The problems may cause a decrease in the bank's profit thereby the manager needs to be careful in providing financing in order to lower the risk of defaults.

A bank's performance and its management function are closely connected. This can be proven when the manager works well the bank will make big profit. According to Novado (2014), bank owners definitely will not hire management which presumably will inflict a financial loss to the company.

There are several kinds of Sharia Commercial Banks' ownership in Indonesia, whether they are state-owned, private, domestic, or foreign. With different kinds of bank ownership, the structure of shares ownership in Sharia Commercial Banks in Indonesia may also vary and is subject to change. A bank may sell some of its shares to investors who are willing to invest their capital in the company. When it happens it will certainly change the composition of stakeholders in the bank.

Considering the importance of relations between bank owners or stakeholders and its management, it is necessary to identify the influence of such relations to the bank's performance. Stakeholders with various backgrounds may affect the manager's policies in decision making. When bank ownership is dominated by the government, like stateowned banks, then the banks' operation will get support from the government. This can be considered as an advantage when compares to banks whose shares are owned by private parties. However, on the other hand this also means that there will be more interference from the government in the company's decision making.

The increasing foreign participation in Indonesia's banking industry is an impact of financial globalization. According to Soedarmono (2011), the participation may take form in the growing number of foreign managers in domestic banking companies, the increasing foreign customers who need services from domestic banks, or the rising external debts due to the incoming flow of foreign capital.

Foreign banks certainly have some advantages compare to domestic banks. According to Bonin et al (2005), foreign banks have better risk management and technological 
innovations, as well as wider access to financial markets. It needs to be realized that Indonesia is a developing country whose technology is less advanced than developed countries. Nevertheless, foreign banks also often experience cultural bias which may create agency problems between foreign and local employees due to the difference in working culture (Novado, 2014).

Based on a previous research, Micco et al (2004) suggested that foreign ownership structure of a bank has positive effects on bank performance. Their research also showed that ownership structure of a state-owned bank has negative effects on profitability. According to a research conducted by Micco, private banks have more significant effects on bank performance. In their research, Uddin and Suzuki (2011) also described that private ownership and foreign ownership have negative effects on banking risks level of Bangladesh banks. The same opinion was offered by Henry (2008) who stated that private ownership has negative effects on the level of banking risks.

As for the problem formulation taken, it is described as follows:

1. Does (domestic, foreign, state-owned, or private) bank ownership affect bank performance in the case of Sharia Commercial Banks in Indonesia?

2. Does (domestic, foreign, state-owned, or private) bank ownership affect bank risks in the case of Sharia Commercial Banks in Indonesia?

\section{Theoretical Background}

Bank owners are any party who takes part in establishing the bank. Bank ownership is stated on the bank's deed of incorporation and structure of shares control (Novado, 2014).

According to Berger et al (2006), banks are classified as follows:

1. Domestic - Foreign Banks

Under this classification, banks are grouped into two types, namely:

(a) Domestic Banks

Domestic banks are banks whose shares are more than $50 \%$ owned by a domestic party, be it the government or national private.

(b) Foreign Banks

Foreign banks are banks whose shares are more than $50 \%$ owned by a foreign party, be it foreign private or foreign government. 


\section{State-owned - Private Banks}

(a) State-owned Banks

State-owned banks are banks whose shares are more than $50 \%$ owned by the government or the state.

(b) Private Banks

Private banks are banks whose shares are more than $50 \%$ owned by a private party, be it national private or foreign private.

According to Dendawijaya in Erlangga (2015), performance is an essential aspect every company of any location and kind has to do well because it reflects the company's ability to manage and allocate its resources in order to optimally reach its goals.

There are several helpful ratios in assessing bank performance. According to Dendawijaya $(2005,119)$, profitability or rentability ratio can be used in assessing the level of bank health. This ratio is highly important since the profit gained from assets utilization reflects the efficiency level of a bank (Nurfahmi, 2014).

In this research, profitability ratio used as an indicator of bank performance is Return on Assets (ROA) because it may function as a standard in assessing bank financial health. Return on Assets (ROA) is one of the profitability ratios. ROA uses profit to assess effectivity in company's assets utilization. According to Weston and Brigham (1990: 304), ROA is a ratio of net profit after taxes to total assets.

Risks are possible events which will inflict a financial loss if they happen (Kountur, 2008: 6). In Islam, whatever happens is an uncertainty and uncertainty is a part of risks.

To assess financing risks faced by banks, Financial Services Authority (OJK) as the bank supervisor board has stipulated several ratios, one of them is a ratio to identify funding quality and reserves adequacy that is Non-Performing Financing (NPF).

In this research, ratio used as an indicator of bank risks is Non-Performing Financing (NPF) because it may function as a standard in assessing bank financial health. BI Circular Letter No. 3/30/DPNP on 14 December 2001 states that Non-Performing Financing (NPF) is a bank financial ratio which reflects the number of non-performing financing compares to total financing.

A bank's size is reflected from the number of assets the company owns. It is important in banking world because banks have to fulfill their financial needs for credit, guarantee, currency and security trade, insurance, financial consultation, and other financial services for customers and investors whose operational behavior is getting more global (Salvatore in Khanani, 2018). 
The age of a bank is one aspect investors take into consideration before investing their capital. According to Novado (2014), the age of a bank can be used to assess the effects of how long a bank has been operating on its performance, which will reflect its ability to survive.

\section{Research Methods}

This research is a study using a quantitative approach. The variables used in this research consist of two exogenous variables, two endogenous variables and one control variable.

1. The exogenous variables in this research are Domestic - Foreign Bank ownership and State-owned - Private Bank ownership.

2. The endogenous variables in this research are Return on Assets (ROA) and Non Performing Financing (NPF).

3. The control variable in this research is Bank Size and Bank Age.

\subsection{Operational definition}

1. ROA is a ratio of net profit after taxes to total assets.

$$
\frac{\text { Profit after Taxes }}{\text { Total Assets }} \times 100 \%
$$

2. Non Performing Financing (NPF) is a bank financial ratio which reflects the number of non-performing financing compares to total financing.

$$
\frac{\text { Total Non Performing Financing }}{\text { Total Financing }} \times 100 \%
$$

3. Bank Size is the total assets a bank owns.

$$
\text { Bank Size }=\text { Ln(Total Assets })
$$

4. Bank Age is the total years the bank has been operating.

$$
\text { Bank Age }=\text { Ln(Total Operating Years) }
$$

\subsection{Analysis models}

Regression models in this research are:

$$
Y_{1 \mathrm{it}}=\beta_{0}+\beta_{1} \mathrm{DF}_{\mathrm{it}}+\beta_{2} \mathrm{SP}_{\mathrm{it}}+\beta_{3} \mathrm{SIZE}_{\mathrm{it}}+\beta_{4} \mathrm{Age}_{\mathrm{it}}+\epsilon
$$




$$
Y_{2 \mathrm{it}}=\beta_{0}+\beta_{5} \mathrm{DF}_{\mathrm{it}}+\beta_{6} \mathrm{SP}_{\mathrm{it}}+\beta_{7} \mathrm{SIZE}_{\mathrm{it}}+\beta_{8} \mathrm{Age}_{\mathrm{it}}+\epsilon
$$

where:

$Y_{1}=$ Return on Assets (ROA)

$\mathrm{Y}_{2}=$ Non Performing Financing (NPF)

$\beta_{0}=$ Constant Coefficient

$\beta=$ Regression Coefficient

DF $=$ Variable of Domestic - Foreign

Bank ownership

$\mathrm{SP}=$ Variable of State-owned - Private

Bank ownership

SIZE = Bank Size (Company Size)

Age $=$ Bank Age (Company Age)

$\varepsilon=$ Error Variable

\section{Results and Discussion}

The object of this research was Sharia Commercial Banks in Indonesia in 2012-2016. The total of Sharia Commercial Banks registered in 2017 was 13 banks. According to the research criteria, there were 10 eligible banks for this research. The list of Sharia Commercial Banks used as research samples was PT. Bank Syariah Mandiri, PT. Bank Muamalat Indonesia, PT. Bank BNI Syariah, PT. BCA Syariah, PT. Bank BRI Syariah, PT. Bank Mega Syariah, PT. Bank Syariah Bukopin, PT. Bank Maybank Syariah Indonesia, PT. Bank Jabar Banten Syariah, PT. Bank Victoria Syariah.

\subsection{Classic assumption tests}

1. Normality Test

For endogenous variable ROA, the value of Kolmogorov-Smirnov $Z$ was 1.287 with Asymp. Sig. of 0.073. For endogenous variable NPF, the value of KolmogorovSmirnov Z was 0.951 with Asymp. Sig. of 0.327. Based on the normality test which has been taken, it can be concluded that the regression models in this research have met the normality assumptions.

2. Heteroscedasticity Test 
Scatterplot diagram showed that for endogenous variable ROA, dots were scattered above and under the zero point of $Y$ axis or vertical axis. Likewise, for endogenous variable NPF dots on scatterplot diagram were dispersed and did not form a typical pattern. Both regression models in this research are feasible since they have met heteroscedasticity assumptions.

\section{Multicollinearity Test}

For multicollinearity test on endogenous variable ROA, all exogenous variables and control variable earned the value of VIF $<10$. Likewise, on endogenous variable NPF, all exogenous variables and control variable earned the value of VIF $<10$. It can be concluded that multicollinearity does not happen to all exogenous variables and control variable in the regression models tested in this research.

\section{Autocorrelation Test}

Durbin-Watson test result for endogenous variable ROA showed a value of 1.451 and for endogenous variable NPF showed the value of 1.231. The values are located in the range between -2 and 2 which means that both regression models in this research have met the autocorrelation test.

\subsection{Hypothetical tests}

Based on the calculation result using IBM SPSS 20 program, here is the result of first equation calculation for endogenous variable ROA:

TABLE 1: Multiple Regression Analysis Results Endogenous Variable ROA.

\begin{tabular}{l|c|c|c|c}
\hline & & \multicolumn{3}{c}{ Regression Models } \\
& Coeffi-cient & $\mathrm{t}$ & Sig. & Conclusion \\
\hline (constant) & 10.043 & 1.452 & 0.154 & \\
\hline DF & 4.423 & 3.371 & 0.002 & Significant \\
\hline SP & -1.596 & -0.908 & 0.369 & Not Significant \\
\hline SIZE & -1.062 & -1.164 & 0.250 & Not Significant \\
\hline Age & 0.495 & 0.350 & 0.728 & Not Significant \\
\hline R Square & 0.238 & & &
\end{tabular}

Based on the table above, the results obtained are as follows:

1. The effects of variable DF on Return on Assets (ROA) show the value of 0.002 with $t_{\text {count }}$ value of 3.371. Therefore the hypotheses in this research are proven where $\mathrm{H}_{1}$ 
is accepted and $\mathrm{H}_{0}$ is declined which means Foreign Bank ownership has positive significant effects on Return on Assets (ROA). Variable DF is a dummy variable with a value of 0 for domestic banks and 1 for foreign banks. This may mean that the one with positive significant effects is banks with a value of 1 , namely foreign banks. On the other hand, the results for domestic banks show that domestic banks have negative significant effects on Return on Assets (ROA).

These results conform to the research conducted by Micco (2004) which stated that foreign bank ownership has positive significant effects on banking Return on Assets (ROA). The results also support research results from Uddin and Suzuki (2011) as well as Lin and Zhang (2009) which mentioned that foreign bank ownership has positive significant effects on banking ROA.

The presence of a foreign party in a bank's ownership may have its own effects. In foreign banks, the management is certainly run by a foreign party. Foreign banks tend to show a higher profitability than domestic banks because foreign parties have relatively better management system, technological innovations, and marketing skills as well as a wider access to financial market when compare to domestic parties. The better policies applied by a bank, the better is its management utilizes the assets. The presence of foreign parties in a bank ownership can also be considered as one way to improve the company's quality in technological aspect in order to increase bank profitability.

2. The effects of variable SP on Return on Assets (ROA) show a significant value of 0.369 with $t_{\text {count }}$ value of 0.908 . Therefore the hypotheses in this research are not proven where $\mathrm{H}_{0}$ is accepted and $\mathrm{H}_{1}$ is declined which means Private Bank ownership has negative not significant effects on Return on Assets (ROA). Variable $\mathrm{SP}$ is a dummy variable with a value of 0 for state-owned banks and 1 for private banks. This may mean that the one with negative not significant effects is banks with a value of 1 , namely private banks. On the other hand, the results for stateowned banks show that state-owned banks have positive not significant effects on Return on Assets (ROA).

These results are different from the research conducted by Micco et al (2004) as well as Uddin and Suzuki (2011) which stated that private bank ownership has positive significant effects on Return on Assets (ROA). According to Uddin and Suzuki (2011), domestic banks are presumably better than state-owned banks from the aspect of banking performance. 
The negative not significant effects between State-owned - Private Bank Ownership and ROA indicate that on average state-owned banks have higher ROA than private banks although the gap is not very significant. This is reflected from the level of state-owned banks' ROA which is more stable and less prone to a financial loss than the one of private banks'. The ROA in private banks is highly fluctuating and in particular years, private banks' ROA can be so low that the banks inflict a financial loss. This implies that state-owned banks are able to maintain their ROA level in a certain value although it is not very high.

3. The effects of control variable SIZE on Return on Assets (ROA) show a significant value of 0.250 with the $t_{\text {count }}$ value of 1.164 . Therefore the hypotheses in this research are not proven where $H_{0}$ is accepted and $H_{1}$ is declined which means variable SIZE has negative not significant effects on Return on Assets (ROA).

The negative not significant effects between Bank Size and ROA indicate that on average bigger banks have lower ROA than smaller banks. This may be affected by external factors beyond this research which were not taken into account in the process, such as banks with bigger total assets will face higher operational costs which are not worth the return earned.

4. The effects of control variable Age on Return on Assets (ROA) shows a significant value of 0.728 with $t_{\text {count }}$ value of 0.350 . Therefore the hypotheses in this research are not proven where $\mathrm{H}_{0}$ is accepted and $\mathrm{H}_{1}$ is declined which means variable Age has positive not significant effects on Return on Assets (ROA).

The positive not significant effects between Bank Age and ROA may cause by the fact that longer established banks certainly have more customers and investors than newly established banks. With more investors, the capital provided for financing is consequently bigger and money velocity is faster thereby return earned is then higher. However, the big fund provided for financing turns out to possibly increase banking financing risks, which is reflected from the research result of the Bank Age effects on NPF.

The high financing risks in long established banks is not worth the Return on Assets (ROA) earned although in the end ROA of those old banks will be higher as well. This indicates the positive not significant relationship between Bank Age and ROA.

The following is the result of first equation calculation for endogenous variable NPF:

Based on the table above, the results obtained are as follows: 
TABLE 2: Multiple Regression Analysis Results Endogenous Variable NPF.

\begin{tabular}{l|c|c|c|c|}
\hline Variables & \multicolumn{4}{c}{ Regression Models } \\
& Coeffi-cient & $\mathrm{t}$ & Sig. & Conclusion \\
\hline (constant) & 82.487 & 7.494 & 0.000 & \\
\hline DF & 11.771 & 5.640 & 0.000 & Significant \\
\hline SP & -17.683 & -6.324 & 0.000 & Significant \\
\hline SIZE & -10.309 & -7.104 & 0.000 & Significant \\
\hline Age & 13.490 & 5.988 & 0.000 & Significant \\
\hline R Square & 0.603 & & & \\
\hline
\end{tabular}

1. The effects of variable DF on Non Performing Financing (NPF) show a significant value of 0.000 with $t_{\text {count }}$ value of 5.640. Therefore the hypotheses in this research are proven where $H_{1}$ is accepted and $H_{0}$ is declined which means Foreign Bank ownership has positive significant effects on Non Performing Financing (NPF). Variable DF is a dummy variable with a value of 0 for domestic bank and 1 for foreign bank. This may mean that the one with positive significant effects is banks with a value of 1 , which is foreign bank. On the other hand, the results for domestic banks show that domestic banks have negative significant effects on Non Performing Financing (NPF).

These results conform to the research conducted by Micco (2004) which stated that foreign bank ownership has positive significant effects on banking Non-Performing Financing (NPF).

The presence of a foreign party in the composition of bank shares ownership will definitely affect the policies each bank will apply. Foreign banks tend to have bigger total assets than domestic banks. This encourages foreign banks to provide easy, big money for financing. This strategy is certainly risky because if the costumers have problems to pay their loan, that will increase the bank NPF. Different from domestic banks, where in this case are Sharia Commercial Banks in Indonesia, which tend not to provide financing in a large sum because the total assets they own are not as big as foreign banks. This carefulness in providing financing which slowly maintains or even lowers the ratio of Non-Performing Financing (NPF) in Sharia Banks.

2. The effects of variable SP on Non-Performing Financing (NPF) shows a significant value of 0.000 with $t_{\text {count }}$ value of 6.324. Therefore the hypotheses in this research are proven where $H_{1}$ is accepted and $H_{0}$ is declined which means private bank ownership has negative significant effects on Non-Performing Financing (NPF). 
Variable SP is a dummy variable with a value of 0 for state-owned bank and 1 for private

bank. This may mean that the one with negative significant effects is banks with a value of 1 , which is private bank. On the other hand, the results for stateowned banks show that state-owned banks have positive significant effects on Non-Performing Financing (NPF).

The same research results were also described in a work of Novado (2014) who stated that private bank ownership has negative significant effects on banking Non-Performing Financing (NPF).

Banks whose shares are dominantly owned by the government often presumably face bigger risks. According to Rowthorn and Chang in Sabrina (2014), the government as a stakeholder does not focus on making maximum profit as its main goal thereby it is lenient in providing financing for its customers without paying meticulous attention to their background. This issue may directly increase the ratio of banking financing risks or Non-Performing Financing (NPF).

According to Novado (2014), private banks have better control on financing risks than state-owned banks. This is because state-owned banks in Indonesia are big banks which provide financing in a large sum as well; thereby the number of non-performing financing is also higher.

3. The effects of control variable SIZE on Non-Performing Financing (NPF) shows a significant value of 0.000 with the $t_{\text {count }}$ value of 7.104. Therefore the hypotheses in this research are proven where $\mathrm{H}_{1}$ is accepted and $\mathrm{H}_{0}$ is declined which means variable SIZE has negative significant effects on Non-Performing Financing (NPF). The increase in total assets which is an indicator of bank size measurement will influence investors' interest in investing their capital. The high investors' interest will add the number of provided fund for financing. When a bank's financing level is high and the management's skills to plan, organize, and supervise its bank are good, the NPF level can be reduced which means smaller ratio of NPF. Meanwhile, medium-sized banks provide the costumers with a large sum of financing but it is not accompanied with good control.

4. The effects of control variable Age on Non-Performing Financing (NPF) shows a significant value of 0.000 . This significant value is smaller than $0.05(0.05>0.000)$ with $t_{\text {count }}$ value of 5.988 which means the $t_{\text {count }}$ is bigger than $t_{\text {table }}$ value $(5.988>1.676)$. Therefore the hypotheses in this research are proven where $H_{1}$ is accepted and 
$\mathrm{H}_{0}$ is declined which means variable Age has positive significant effects on NonPerforming Financing (NPF).

The results of this research indicate that the older the bank the more active the bank is in running its operational activities because old banks have earned higher trust from the public. Reliable banks may increase investors' trust to invest their capital in the banks. The high operational activities and fast capital velocity in a bank especially in terms of financing moreover in a large sum since the capital owned is also large are expectedly to bring more return. However, the large fund for financing provided by a bank may increase the bank's ratio of Non-Performing Financing (NPF).

\section{Conclusions}

The results of this research indicate that Foreign Bank ownership has positive significant effects on Return on Assets (ROA), Private Bank ownership has negative not significant effects on Return on Assets (ROA), Foreign Bank ownership has positive significant effects on Non-Performing Financing (NPF), and Private Bank ownership has negative significant effects on Non-Performing Financing (NPF).

\section{References}

[1] Berger, A.N. and L. F. Klapper and M. S. Martinez Peria and Rida Zaidi. 2006. Bank Ownership Type and Banking Relationships. Journal of Finance Intermediation

[2] Bonin, J.P. and I. Hasan and P. Wachtel. 2005. Bank Performance, Efficiency and Ownership in Transition Countries. Journal of Banking and Finance. 29 pp. 31-53

[3] Dendawijaya, Lukman. 2005. Manajemen Perbankan. Jakarta: Ghalia Indonesia

[4] Erlangga, Okyviandi Putra. 2015. Analisis Pengaruh Ukuran Perusahaan, Kecukupan Modal, Likuiditas dan Pembiayaan Bermasalah Terhadap Profitabilitas Bank Umum Syariah di Indonesia Periode Januari 010-Desember 2014. Skripsi. Fakultas Ekonomi dan Bisnis. Universitas Airlangga

[5] Henry, Tan. 2008. Analisis Perbedaan Kinerja Keuangan Antara Bank Asing dan Bank Umum di Indonesia. Tesis Universitas Gunadarma

[6] Khanani, Fildzah Nur. 2018. Pengaruh Non Performing Financing, Financing to Deposit Ratio, dan Bank Size Terhadap Efisiensi Bank Pada Bank Umum Syariah di Indonesia Tahun 2012-2016. Skripsi. Fakultas Ekonomi dan Bisnis. Universitas Airlangga 
[7] Kountur, Ronny. 2008. Mudah Memahami Manajemen Risiko Perusahaan. Jakarta: Penerbit PPM

[8] Lin, Xiaochi dan Yi Zhang. 2009. Bank Ownership Reform and Bank Performance in China. Journal of Banking \& Finance. 33, 20-29

[9] Micco, Alejandro and Ugo Paniza and Monica Yanez. 2004. Bank Ownership and Performance. Research Department Working Papers

[10] Novado, Andre. 2014. Kinerja Perbankan Pada Kepemilikan: Domestik, Asing, Pemerintah, Swasta. Jurnal Bisnis \& Manajemen. Vol. 14, No. 2, 2014: 51-66

[11] Nurfahmi, Harish Ari. 2014. Analisis Pengaruh Rasio Keuangan Terhadap Kinerja Bank (Studi pada Perbankan yang Terdaftar di BEI Tahun 2010-2012). Skripsi. Fakultas Ekonomika dan Bisnis Universitas Diponegoro

[12] Sabrina, Farah Nur. 2014. Analisis Pengaruh Kepemilikan Pemerintah, Kepemilikan Asing, Rasio Likuiditas, dan Risiko Kredit Terhadap Kinerja Keuangan Bank. Skripsi. Fakultas Ekonomika dan Bisnis. Universitas Diponegoro

[13] Siregar, Mustafa. 1990. Efektivitas Perundang-undangan Perbankan dengan Penelitian di Wilayah Kotamadya Medan. Ringkasan Disertasi. Medan

[14] Soedarmono, Wahyoe. 2011. Bank Capital Inflows, Institutional Development and Risk: Evidence From Publicly - Traded Banks in Asia. Buletin Ekonomi, Moneter dan Perbankan

[15] Sudana, I Made. 2011. Manajemen Keuangan Perusahaan Teori dan Praktek. Jakarta: Erlangga

[16] Uddin, S. M. Sohrab and Yasushi Suzuki. 2011. Financial Reform, Ownership and Performance in Banking Industry: The Case of Bangladesh. International Journal of Business and Management. Vol. 6, No. 7, pp 28-39

[17] Weston, J. Fred and Eugene F. Brigham. 1990. Dasar-Dasar Manajemen Keuangan (Edisi Kesembilan). Jakarta: Penerbit Erlangga 